\title{
The impact of primary school teachers' educational beliefs on the classroom use of computers
}

\author{
R. Hermans*, J. Tondeur, J. van Braak, M. Valcke \\ Ghent University, Department of Educational Studies, Dunantlaan 2, 9000 Ghent, Belgium
}

Received 1 May 2007; received in revised form 25 January 2008; accepted 3 February 2008

\begin{abstract}
For many years, researchers have searched for the factors affecting the use of computers in the classroom. In studying the antecedents of educational computer use, many studies adopt a rather limited view because only technology-related variables, such as attitudes to computers and computer experience were taken into account. The present study centres on teachers' educational beliefs (constructivist beliefs, traditional beliefs) as antecedent of computer use, while controlling for the impact of technology-related variables (computer experience, general computer attitudes) and demographical variables (sex, age). In order to identify differences in determinants of computer use in the classroom, multilevel modelling was used $(N=525)$. For measuring primary teachers' use of computers to support the leaching or learning process a modified version of the 'Class Use of Computers' scale of van Braak et al. [van Braak, J., Tondeur, J., \& Valcke, M. (2004). Explaining different types of computer use among primary school teachers. European Journal of Psychology of Education, 19(4), 407-422] was used. The present article supports the hypothesis that teacher beliefs are significant determinants in explaining why teachers adopt computers in the classroom. Next to the impact of computer experience, general computer attitudes and gender, the results show a positive effect of constructivist beliefs on the classroom use of computers. Traditional beliefs have a negative impact on the classroom use of computers.
\end{abstract}

(c) 2008 Elsevier Ltd. All rights reserved.

Keywords: Elementary education; Media in education; Pedagogical issues; Teacher beliefs

\section{Introduction}

The history of education is characterised by successive innovations that aim at the implementation of higher quality. For many years, scholars have pursued more effective, efficient and/or satisfying teaching and learning practices. This is reflected in the adoption of a variety of curriculum approaches that have shifted from a mental discipline and humanistic tradition to approaches that centre on social efficiency, child development and/or social meliorism that aim at empowering learners to advance society (Kliebard, 1989).

\footnotetext{
* Corresponding author. Tel.: +32926486 74; fax: +3292648688.

E-mail address: Ruben.Hermans@UGent.be (R. Hermans).
} 
Whereas traditional instructional methods have been criticised for failing in preparing students to meet the challenges of contemporary society, the current educational focus is on learner-centered constructivist approaches (Hannafin \& Land, 1997). The latter has affected the decision-making process of teachers about the types of learning objectives, the learning content, the selection of media, organisational issues, the choice of instructional strategies and the adoption of approaches towards assessment and evaluation. However, the slow uptake of the innovative ideas in mainstream education questions the success of the implementation of the innovative approach. As Fullan (2001) pointed out, the perceptions of the actors involved in educational innovations are a critical factor in the success of an innovation. Therefore, the notion that teachers are to be considered the most crucial player in educational change is not surprising (Van Driel, Verloop, Van Werven, \& Dekkers, 1997). It is stated that past educational reforms have failed, due to the mismatch between the meanings attached to the innovation by those involved in the instructional process (Van den Berg, Vandenberghe, \& Sleegers, 1999). In this respect, the personal willingness of teachers to adopt and integrate innovations into their classroom practice seems to be of crucial importance (Ghaith \& Yaghi, 1997).

In the present study, we focus on an educational innovation that builds upon the integration of computers in classroom practice. According to Watson (2006), the introduction of information and communication technologies (ICT) is often inspired by a widespread and technocentric belief about the transformative nature of these new technologies. This assumption assigns to technology the capacity to support powerful and sophisticated learning environments. Technology is seen as a golden key in facilitating technology-enhanced, student-centred teaching environments (Hannafin \& Land, 1997). According to these authors, technology provides opportunities for access to resources and tools that facilitate the construction of personal meaning by relating new knowledge to existing conceptions and understanding. However, the current level of ICTimplementation of ICT has yet not reached a critical mass (Scrimshaw, 2004) and there is a tension between the input of enthusiastic forerunners and the reality of a more widespread implementation (Watson, 2006). For example, research of Tondeur, van Braak, and Valcke (2006) on the link between national curricula and the use of ICT in primary education in Flanders has shown that Flemish primary school teachers still to a large extent stress technical ICT skills. Smeets (2005) also argues that current ICT use in Dutch primary schools seems to reflect a rather traditional, skills-oriented instructional use with the emphasis on skills-based applications.

The gap between the innovation objectives and the current level of ICT integration has inspired researchers to focus on the individual factors affecting the nature of ICT adoption in the classroom. Identification of factors explaining computer use might provide answers to why some teachers embrace the use of computers in the classroom and others do not. In search of antecedents of computer use, many studies focussed thus far on teacher attitudes, computer self-efficacy and computer proficiency (e.g., Albirini, 2006; Demetriadis et al., 2003; van Braak, Tondeur, \& Valcke, 2004). These studies try to explain educational computer use mainly through technology-related teacher characteristics. Within the context of the present study, this list of technological determinants is extended with educational beliefs. The main contention is that teachers' classroom use of computers cannot be fully understood without taking their underlying educational beliefs into consideration (Becker, 2001; Dede, 2000).

\section{Theoretical framework}

\subsection{The concept of teacher beliefs}

It is difficult to describe teacher beliefs in unequivocal terms considering the myriad ways they have been defined in the research literature. However, building on the substantial body of literature about teacher beliefs and teacher belief systems, a list of shared defining characteristics can be developed. A first defining characteristic is that teacher beliefs can be considered to be 'the individual conceptions about desirable ways of teaching and conceptions about how students come to learn' (Beijaard, 1998). Those beliefs are grounded in teachers' personal belief systems and represent psychologically held understandings, premises, or propositions felt to be true (Richardson, 2003). The set of someone's beliefs about the physical, the social world, and the self is clustered in a belief system (Rokeach, 1976). In fact, belief system seems to consist of an eclectic mix of rules of thumb, generalisations, opinions, values, and expectations grouped in a more or less structured way 
(Lowyck, 1994; Rokeach, 1976). In primary education, examples of belief systems are reflected in teacher-centred and learner-centred approaches towards teaching (e.g., Jackson, 1986; Schuh, 2004).

Second, teacher beliefs are established by earlier experiences and influenced by the professional context (Pajares, 1992). By the time students enter teacher education programs, their beliefs are already shaped by their personal experiences as pupils (Keys, 2007; Pajares, 1992; Raths, 2001). As a result, teachers' beliefs appear to be relatively stable and resistant to change (Kagan, 1992; Pajares, 1992; Van Driel et al., 1997). According to Rokeach (1976), the stability of a belief is also clear when considering the position of beliefs within the central-peripheral dimension in a person's belief system. That is to say, the more a belief is related to other beliefs, the more it is positioned at the centre of the belief system and the less this belief is subject to change.

The former implies that it is important to consider the mediating impact of beliefs in the adoption process of educational innovations. Teacher beliefs appear to influence teaching practices and their identity (e.g., Clark \& Peterson, 1986; Fang, 1996; Kagan, 1992; Kane, Sandretto, \& Heath, 2002; Pajares, 1992; Prawat, 1992; Zeichner \& Tabachnick, 1985). This is particularly true when educational innovations centre on classroom related phenomena that teachers have to deal with as a complex set of interacting variables and processes, and related to a variety of actors such as pupils, parents, colleagues, management, etc. (Bruner, 1996; Uhlenbeck, Verloop, \& Beijaard, 2002). At a micro-level, teachers enter the teaching setting with their personal theories about teaching and learning, as well as their personal interpretation of the instructional situation (Shulman, 1987; Uhlenbeck et al., 2002). This reinforces the earlier statement that teachers are important agents in the concrete implementation of an innovation process within a classroom setting (Albirini, 2006; Van Driel et al., 1997).

\subsection{The concept of teachers' educational beliefs related to ICT}

As part of the worldwide proliferation of ICT use in society, ICT has entered the educational field in a pervasive way and is often credited with the potential to revolutionise a so-called outmoded educational system (Albirini, 2006). ICT is expected to offer both a means to operationalise constructivist principles and to create effective constructivist learning environments (Bellefeuille, 2006). Smeets (2005), for example, investigates Dutch primary teachers' views regarding the potential contribution of ICT to the creation of powerful learning environments in which the emphasis is laid on rich contexts and authentic tasks for the pupils, where active and autonomous learning is stimulated, where cooperative learning is fostered, and where the curriculum is tailored to the needs and capabilities of individual pupils. Furthermore, educationists expect ICT to help students to meet the challenges of the fast-changing world (Hawkridge, 1990; Kearns \& Grant, 2002). For example, students need to learn how to seek information, to think critically, and to take initiatives. ICT is expected to mediate in this process of socialisation and enculturation (Dede, 2000; Lim, 2002).

In order to realise the potential of ICT, national governments have supported ICT's integration in education. For example, in the Flemish educational context where this study is based, cross-curricular attainment targets for ICT have been prescribed for primary education (Ministry of the Flemish Community, 2007). Here, ICT is no longer seen as a particular knowledge domain, but rather as a supportive tool to improve teaching and learning. Nevertheless, the current level of ICT-implementation in primary schools remains rather restricted (Scrimshaw, 2004). In addition, research evidence also reveals that significant differences can be observed between and within schools in the way ICT is currently being implemented (e.g., Goodison, 2002; Loveless \& Dore, 2002). For example, in reviewing both the municipal and school ICT plans in Denmark, Bryderup and Kowelski (2002) noticed significant differences between schools regarding the forms and content of the individual plans, varying from an emphasis on pedagogical considerations to more instrumental accents. Other differences were found concerning the description of content and details on how goals were to be achieved. Similar remarks were made in a recent study of Tondeur et al. (2006) on the integration of ICT competency frameworks in Flemish primary education. Their study revealed that government-imposed ICT competencies do not automatically result in changes in classroom practices.

Recent research about differences in ICT adoption by teachers is often limited to technology-related variables, such as 'computer experience' (Becker, 2001; Williams, Coles, Wilson, Richardson, \& Tuson, 2000) and 'attitudes towards computers' (Albirini, 2006; van Braak, 2001). A general finding is that computer experience 
is positively related to computer attitudes. The more experience teachers have with computers, the more likely they will report positive attitudes towards computers (Rozell \& Gardner, 1999). Positive computer attitudes are expected to foster computer integration in the classroom (van Braak et al., 2004). Other factors frequently related to ICT integration include age (e.g., Bradley \& Russell, 1997) and gender (e.g., Shapka \& Ferrari, 2003). Many researchers have stressed the 'gender gap' in computer use. Studies report e.g., lower levels of classroom use of computers by female teachers (van Braak et al., 2004).

However, building on the earlier discussion about the relationship between educational innovations and teacher beliefs, the process of ICT integration cannot solely be explained by referring to technology-related variables and/or demographic variables. As stated earlier, at a more individual level, teachers' educational use of computers can only be fully understood when taking into account their educational beliefs (Becker, 2001; Dede, 2000). Recent studies demonstrate that teacher beliefs about learning and instruction are indeed a critical indicator for the classroom use of computers (Becker, 2001; Dede, 2000; Ertmer, 2005). On the one hand, research indicates that teacher beliefs can be barriers to ICT integration (Ertmer, 2005). On the other hand, findings suggest that highly active computer users seem to adopt a constructivist position (Becker, 2001). This is in line with Duffy and Jonassen's statement (1992) about the strong correlation between ICT use and the constructivist perspective. Yet, individual's decisions to accept technology is "affected by multiple key factors or considerations pertinent to the technology, the user and the organizational context" (Hu, Clark, \& Ma, 2003:227).

The available research evidence clearly illustrates that the question of ICT integration cannot only be explained by referring to teacher demographics or computer proficiency, experience and attitudes. Rather, it seems to be valid to shift the focus towards a broader debate about the central role and position of mindsets, assumptions, beliefs, and values of individuals and organisations (Tearle, 2003).

\subsection{Research objectives}

The present study links questions about the integration of computer use in the classroom to research about teacher thinking and the innovation of primary education. The purpose of the present study is to investigate the relationship between teachers' educational beliefs and their computer use, while controlling for the impact of technology-related determinants (computer experience, supportive computer use, general computer attitudes) and teacher-related demographic variables (gender and age). To study this complex relationship, multilevel modelling will be applied.

\section{Methodology}

\subsection{Participants}

In order to empirically investigate the effect of teachers' educational beliefs on the classroom use of computers, a questionnaire was administered to a sample of 525 primary school teachers from 68 schools in Flanders (the Dutch-speaking area of Belgium). The participants were distributed evenly across all primary school grades. Of the respondents, $81 \%$ were female and 19\% were male. Ages ranged from 22 to 64 years old $(M=37, \mathrm{SD}=10)$.

\subsection{Statistical analysis approach}

Nevertheless, building on the earlier discussion about the nature and the development of teacher beliefs and belief systems, interplay can be assumed between teachers as individuals and the social context (team or school) to which they belong. It can also be hypothesised that the properties of the particular social context influence individual teacher beliefs and in turn this context is also influenced by the individuals who make up the particular social context. In other words, the observations of individual teachers are not completely independent of what teachers share in their school setting (Hox, 1995). This assumption strongly determines the nature of the statistical analysis procedures to be adopted when studying teacher beliefs. While standard linear 
regression techniques attempt to explain the variation in a dependent variable (such as classroom use of computers) in terms of one or more independent variables (such as teacher demographics or computer experience), the adoption of multilevel modelling techniques is helpful to take different levels within a hierarchy of nested variables into account (Gorard, 2003). It is critical to recognize that within- and between-subject level relationships are independent (Nezlek, 2001). For this reason, Nezlek (2001) stipulates that using techniques that do not examine "phenomena at different levels simultaneously can provide misleading descriptions of the relationships within a data set".

In the present study, teachers $(N=525)$ are nested within 68 Flemish primary schools. Therefore, the problem under investigation reflects a typical hierarchical structure. For this reason, multilevel modelling (MLwiN 2.02) was applied to investigate the effect of demographics, computer experience in years, general computer attitudes, supportive computer use in hours, and teachers' constructivist and traditional beliefs on the classroom use of computers.

Considering the aim of the study, three main models will be tested. After testing the null model, a compound model will be created by respectively adding teacher demographics, technology-related variables and teacher beliefs to the null model. Stepwise multilevel modelling enables us to check the additional value for each consecutive model. In doing so, the different subsets of variables can be compared to one another as to the proportion of explained variance. Model improvement is assessed by studying the decrease in the deviance value compared to the previous model. Within this respect, the difference in deviance is used as a test statistic having a chi-squared distribution (Hox, 1995; Snijders \& Bosker, 1999).

\subsection{Variables}

\subsubsection{Dependent variable}

3.3.1.1. Classroom use of computers. In this study, ICT is delineated to the classroom use of computers. To examine this dependent variable, a modified version of the 'Class Use of Computers' scale of van Braak et al. (2004) was used. Items in this scale $(n=8)$ build on a five-point scale: 0 (never), 1 (once a term), 2 (monthly), 3 (weekly) and 4 (daily).

\subsubsection{Independent variables}

3.3.2.1. Teacher beliefs: constructivism and traditionalism. The 'Constructivist Beliefs' and 'Traditional Beliefs' scale of Woolley, Benjamin, and Woolley (2004) was used in this study. Whereas 'Constructivist Beliefs' $(n=7)$ focuses on constructivist, student-centered approaches to teaching and learning, 'Traditional Beliefs' $(n=9)$ mainly zoom in on a teacher-centered approach (Hermans, van Braak, \& Van Keer, 2008; Woolley et al., 2004). Items in both scales are rated by using a five-point Likert scale ranging from 'totally disagree' to 'totally agree'.

3.3.2.2. Teacher demographics. Building on the theoretical framework, gender and the teacher's age are expected to influence the classroom use of computers.

3.3.2.3. Computer experience and supportive use of computers. Respondents were questioned about their computer experience expressed in number of years. Each respondent was asked to indicate the number of years he or she had been using computers. Beside computer experience, respondents were also asked to calculate the extent to which they use computers to support their classroom practices in numbers of hours (e.g., use of a computer as a diary, to prepare lessons or to develop materials).

3.3.2.4. Computer attitudes. The instrument used for measuring computer attitudes is the 'General Attitudes Towards Computers' of van Braak and Goeman (2003). The scale comprises items related to computer liking, computer anxiety and computer confidence. Items in the scale $(n=5)$ build on a five-point Likert scale ranging from 'totally disagree' to 'totally agree'. The items help to calculate an overall value for the variable 'General Computer Attitude', varying within a 0-100 range. The higher the scale score, the more positive the attitudes towards working with computers. 


\section{Research results}

\subsection{Descriptive statistics and reliability of the research instruments}

In the questionnaire, to measure the dependent variable 'Class Use of Computers', a total of eight items was included covering different applications of the classroom use of computers. As shown in Table 1, the three most applied applications of 'Class Use of Computer' were (1) 'use of educational software for training skills', (2) 'differentiation' and (3) 'cooperative learning'.

The mean scores for the teacher belief scales 'Constructivism' and 'Traditionalism' were $M=64.7$ $(\mathrm{SD}=12.2)$ and $59.3(\mathrm{SD}=11.7)$ respectively (see Table 2$)$. The average computer experience was 10.34 years. With respect to supportive computer use, primary teachers reported using the computer 5.93 hours a day for pre-active and post-active tasks. Concerning 'General Computer Attitudes', with a mean score of $M=72.0$ $(\mathrm{SD}=18.9)$, primary school teachers indicated a predisposition towards computers. Finally, building on the individual item scores, an overall scale score was calculated and reliability of the instruments was examined using Cronbach's alpha. As shown in Table 2, all instruments showed satisfactory internal consistency.

\subsection{Multilevel model}

\subsubsection{Null model}

Since no independent variables at teacher level (level 1) were included in the random intercept null model, the intercept of the null model (Model 0) represents the overall mean of the score on the 'classroom use of computers' of all teachers in all schools. Scrutinising the results reported in Table 3, we find clear support for applying multilevel modelling in studying the classroom use of ICT. Both variances at teacher level $\left(\chi^{2}=228.75, \mathrm{~d} f=1, p<0.001\right)$ and school level $\left(\chi^{2}=12.86, \mathrm{~d} f=1, p<0.001\right)$ are significantly different from zero. The proportion of variance attributed to between-school differences can be calculated by dividing the total variance of the 'Class Use of Computers' $(57.674+259.313)$ by the within-school $(259.313)$ variance. This results in $18.19 \%$ of the variance to be attributed to differences between schools, and $81.81 \%$ of the variance due to differences at the teacher level.

\subsubsection{Model 1}

As mentioned above, in earlier research, demographical teacher variables such as gender and age have been found to influence the classroom use of computers. In a first model, 'Gender' and 'Age' were added to the fixed part of the model (Model 1a). Since 'Age' $\left(\chi^{2}=0.121, \mathrm{~d} f=1, p=0.73\right)$ did not contribute significantly, it was excluded from the model. But a significant effect of 'Gender' (Model 1b) was observed with an average difference in favour of males $\left(\chi^{2}=15.549, \mathrm{~d} f=1, p=<0.001\right)$. Compared to the null model, the inclusion of 'Gender' resulted in a significant model improvement $\left(\chi^{2}=31.347, \mathrm{~d} f=1, p<0.001\right)$.

Table 1

Descriptives of the 'Class Use of Computer Scale'

\begin{tabular}{|c|c|c|c|c|c|c|c|}
\hline & $M$ & $\mathrm{SD}$ & $\begin{array}{l}\text { Never } \\
(\%)\end{array}$ & $\begin{array}{l}\text { Half a year } \\
(\%)\end{array}$ & $\begin{array}{l}\text { Monthly } \\
(\%)\end{array}$ & $\begin{array}{l}\text { Weekly } \\
(\%)\end{array}$ & $\begin{array}{l}\text { Daily } \\
(\%)\end{array}$ \\
\hline Encouraging pupils to train skills & 2.11 & 1.076 & 8.9 & 20.0 & 28.0 & 37.1 & 6.0 \\
\hline As a tool for differentiation & 1.86 & 1.250 & 20.6 & 16.9 & 25.5 & 29.8 & 7.2 \\
\hline Encouraging cooperative learning & 1.83 & 1.154 & 16.9 & 21.4 & 27.2 & 30.4 & 4.1 \\
\hline Asking pupils to do assignments on the computer & 1.66 & 1.257 & 26.5 & 17.5 & 23.3 & 28.5 & 4.2 \\
\hline $\begin{array}{l}\text { Encouraging pupils to search for information on the } \\
\text { internet }\end{array}$ & 1.34 & 1.239 & 37.5 & 16.2 & 23.8 & 19.7 & 2.7 \\
\hline As a tool for demonstration & 0.97 & 1.100 & 46.6 & 23.1 & 19.0 & 9.4 & 2.0 \\
\hline As a tool for instruction & 0.96 & 1.145 & 49.5 & 21.1 & 15.3 & 12.2 & 1.9 \\
\hline Teaching about the possibilities of computers & 0.69 & 0.989 & 59.8 & 20.6 & 11.3 & 7.8 & 0.6 \\
\hline
\end{tabular}


Table 2

Descriptives, reliability coefficients and correlates

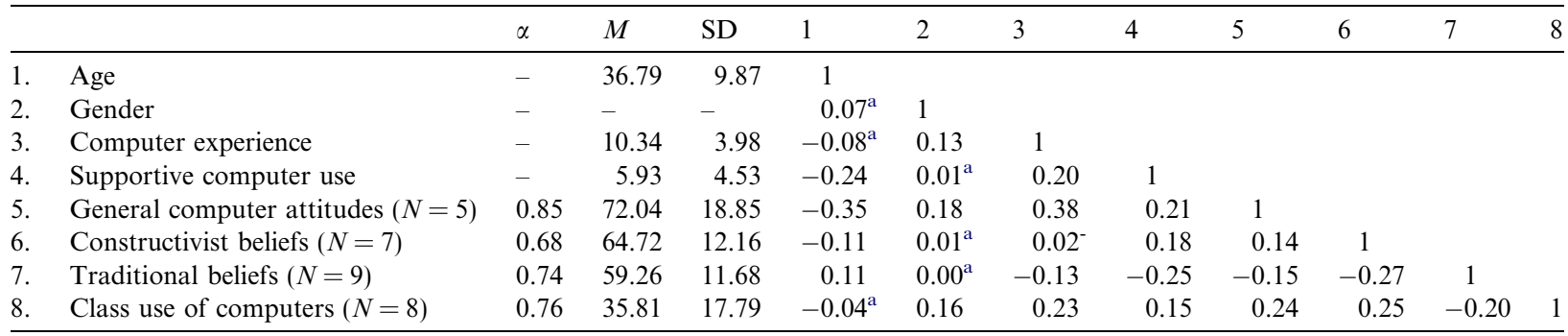

${ }^{a}$ Correlation is non-significant.

\subsubsection{Model 2}

At a second stage of model specification, a compound model including teacher gender and technologyrelated variables was estimated (Model 2). Considering the non-significant effect of 'Supportive Computer Use' in Model 2a $\left(\chi^{2}=2.94, \mathrm{~d} f=1, p=0.09\right)$, this variable was omitted from further analyses. Next to a significant contribution of 'Gender' $\left(\chi^{2}=9.42, \mathrm{~d} f=1, p<0.01\right)$, 'Computer Experience' and 'General Computer Attitudes' also contribute in a significant way $\left(\chi^{2}=10.93, \mathrm{~d} f=1, p<0.001, \chi^{2}=12.44, \mathrm{~d} f=1, p<0.001\right.$, respectively). The intercept of 35.01 in Model 2b stands for the overall mean across female teachers with an average score on 'Computer Experience' and 'Computer Attitudes'. Model improvement by moving from Model 1 to Model $2 \mathrm{~b}$ was clearly significant $\left(\chi^{2}=86.69, \mathrm{~d} f=1, p<0.001\right)$.

Table 3

Estimates from a random intercept model (dependent variable: 'Class Use of Computers')

\begin{tabular}{|c|c|c|c|c|c|c|}
\hline & Model $0 B$ & Model 1a $B$ & Model 1b $B$ & Model 2a $B$ & Model 2b $B$ & Model $3 B$ \\
\hline \multicolumn{7}{|l|}{ Fixed } \\
\hline Intercept & $36.13(1.19)^{* * *}$ & $34.87(1.23)^{* * *}$ & $34.86(1.23)^{* * *}$ & $35.10(1.17)^{* * *}$ & $35.01(1.17)^{* * *}$ & $34.73(1.11)^{* * *}$ \\
\hline Age & & $-0.027(0.08)$ & - & - & - & - \\
\hline Gender (man) & & $7.59(1.92)^{* * *}$ & $7.55(1.91)^{* * *}$ & $6.56(1.93)^{* *}$ & $5.82(1.90)^{* *}$ & $6.45(1.85)^{* * *}$ \\
\hline Computer experience & & & & $0.55(0.20)^{* *}$ & $0.64(0.19)^{* * *}$ & $0.66(0.19)^{* * *}$ \\
\hline Supportive computer use & & & & $0.29(0.17)$ & - & - \\
\hline $\begin{array}{l}\text { General computer } \\
\text { attitudes }\end{array}$ & & & & $0.12(0.04)^{*}$ & $0.14(0.04)^{* * *}$ & $0.09(0.04)^{*}$ \\
\hline Traditionalism & & & & & & $-0.17(0.06)^{* * *}$ \\
\hline Constructivism & & & & & & $0.29(0.06)^{* *}$ \\
\hline \multicolumn{7}{|l|}{ Random } \\
\hline Level 2 - school $\sigma^{2} u_{0}$ & $57.67(16.39)^{* * *}$ & $57.01(16.18)^{* * *}$ & $57.53(16.21)^{* * *}$ & $48.89(14.57)^{* * *}$ & $50.62(14.67)^{* * *}$ & $43.93(13.13)^{* * *}$ \\
\hline Level 1 - teacher $\sigma^{2} e_{0}$ & $\begin{array}{l}259.31 \\
(17.15)^{* * *}\end{array}$ & $\begin{array}{l}252.35 \\
(16.74)^{* * *}\end{array}$ & $\begin{array}{l}251.70 \\
(16.68)^{* * *}\end{array}$ & $\begin{array}{l}235.42 \\
(15.93)^{* * *}\end{array}$ & $\begin{array}{l}235.85 \\
(15.73)^{* * *}\end{array}$ & $\begin{array}{l}219.44 \\
(14.73)^{* * *}\end{array}$ \\
\hline \multicolumn{7}{|l|}{ Model fit } \\
\hline Deviance & 4455.907 & 4416.969 & 4424.56 & 4226.792 & 4337.868 & 4248.168 \\
\hline$\chi^{2}$ & & & 31.347 & & 86.692 & 89.7 \\
\hline $\mathrm{d} f$ & & & 1 & & 2 & 2 \\
\hline$p$ & & & $<0.001$ & & $<0.001$ & $<0.001$ \\
\hline Reference & & & M0 & & M1b & $\mathrm{M} 2 \mathrm{~b}$ \\
\hline \multicolumn{7}{|l|}{ Variance } \\
\hline$\rho(\%)$ & 18.19 & & 18.60 & & 17.67 & 16.68 \\
\hline
\end{tabular}

Note. Values between brackets are the standard errors.

${ }^{*} p<0.05$.

${ }^{* *} p<0.01$.

*** $p<0.001$. 
Table 4

Proportion of variance explained at each level

\begin{tabular}{|c|c|c|c|}
\hline & Model 1b & Model 2b & Model 3 \\
\hline$R_{\text {micro }}^{2}$ (Proportion of variance explained at teacher level) & 0.024 & 0.096 & 0.169 \\
\hline$\Delta R_{\text {micro }}^{2}$ & & 0.072 & 0.073 \\
\hline$R_{\text {micro }}^{2}$ (Proportion of variance explained at teacher level) & 0.012 & 0.111 & 0.207 \\
\hline$\Delta R_{\text {micro }}^{2}$ & & 0.098 & 0.097 \\
\hline
\end{tabular}

\subsubsection{Model 3}

At the final stage, Model 2 was extended by adding teacher beliefs to the regression equation (Model 3 ). This final model allows us to explore whether teachers' beliefs have a significant effect on the classroom use of computers. The analysis results confirm the latter and support the assumption that constructivist beliefs about teaching and learning have a significant positive effect on the 'Class Use of Computers' $\left(\chi^{2}=21.69\right.$, $\mathrm{d} f=1, p<0.001)$. By contrast, traditional beliefs were found to have a negative impact $\left(\chi^{2}=7.36, \mathrm{~d} f=1\right.$, $p<0.05)$. Other significant determinants of the 'Class Use of Computers' were 'Gender' $\left(\chi^{2}=12.96, \mathrm{~d} f=1\right.$, $p<0.001)$, 'Computer Experience' $\left(\chi^{2}=11.85, \mathrm{~d} f=1, p<0.001\right)$, and 'Computer Attitudes' $\left(\chi^{2}=5.71\right.$, $\mathrm{d} f=1, p<0.05)$. Compared to Model $2 \mathrm{~b}$, the final model results in a significantly better fit $\left(\chi^{2}=89.7\right.$, $\mathrm{d} f=1, p<0.001)$. As can been seen in Table 3, 16.68\% of variance in the dependent variable is to be situated at school level.

Finally, in order to investigate the additional contribution of each subset of variables in explaining a proportion of variance in the regression model, the squared multiple correlation coefficient $\left(R^{2}\right)$ can be computed based on the method of Snijders and Bosker (1999). The variance explained is divided into the variance accounted for both at teacher and at school level. Table 4 presents the $R^{2}$ at teacher $\left(R_{\text {micro }}^{2}\right)$ and school level $\left(R_{\text {macro }}^{2}\right)$ for each model. Calculation of the added value $(\Delta R)$ gives us insight in the proportion of variance explained by each individual subset. As shown in Table 4, an increase in the proportion of variance of $7.2 \%$ at teacher and $9.8 \%$ at school level can be noticed for Model $2 \mathrm{~b}$ (compared to Model $1 \mathrm{~b}$ ). The additional contribution in the proportion of explained variance is explained by the extension of Model 1b with the technological-related variables 'Computer Experience' and 'General Computer Attitudes'. Correspondingly, by adding teacher beliefs to Model $2 \mathrm{~b}$, the results show an increase of $7.3 \%$ at teacher level and $9.7 \%$ at school level (Model 3). As becomes clear from Table 4, the additional proportion of variance explained by teacher beliefs and technology-related variables is comparable at teacher and school level.

\section{Discussion and conclusions}

In this study, empirical evidence was found supporting the hypothesis that teacher beliefs about the practice of teaching are a significant determinant in explaining why teachers adopt computers in the classroom. Though the reported classroom use of ICT can hardly be described as 'innovative' in nature, constructivist teacher beliefs were found to be a strong predictor of classroom use. In contrast, traditional teacher beliefs seem to have a negative impact on the integrated classroom use of computers. These findings are in line with earlier research suggesting that teachers with a strong constructivist orientation are more prone to adopting tools that foster constructivist learning approaches (Riel \& Becker, 2000). Next to the impact of educational beliefs, the final multilevel analysis model shows that gender, computer experience and general computer attitudes do have a significant effect on the class use of computers.

Furthermore, the stepwise approach in the multilevel modelling analysis allowed studying the complex interplay of beliefs, demographic, and technology-related variables, and this both at teacher and school level. The additional contribution in the proportion of explained variance by demographic, technology-related variables and educational beliefs could be compared with one another. Building on the results, teacher beliefs seem to be at least as important as technology-related teacher characteristics such as computer experience, general computer attitudes and gender. Therefore, and this is an important result, the present study sheds light on the mediating role of primary teachers' educational beliefs in the resistance and receptiveness of primary school 
teachers to integrate computers in their classroom practice. As mentioned earlier, the teacher as an "innovator" or "preserver" is a critical actor to influence change in the classroom (Albirini, 2006; Watson, 2006). In further investigations, the focus of research can be extended to teachers' attributions and perceptions about the extent to which ICT might play a role in supporting their teaching. Furthermore, the dominant role of beliefs as a mediating factor in adopting educational innovations has major implications for professional teacher development (Watson, 2006).

At school level, the results point to the need to emphasise the educational context. Since about $18 \%$ of the variance in the dependent variable is related to the school level, these results also suggest a shared set of educational beliefs in particular schools. This introduces a further direction for future research that centres on specific school conditions and school culture variables. This can be related to the statement of Pajares (1992) that teachers can form mutually supportive groups in which their participation is based on sharing their particular beliefs. Belonging to these groups enables teachers to gain confidence. Also Paris and Combs (2006) point at this topic when they discuss the concept "meaning giving". They conclude that teachers share teaching practices and the meaning assigned to these practices in a particular school context. Similarly, it might be interesting to investigate whether teachers' educational beliefs are part of a culture, shared and/or negotiated at school level. Though the purpose of the present study focussed primarily on the relationship between primary school teachers' educational beliefs and the classroom use ICT (both variables at the teacher level), the results indicate multilevel modelling as a worthwhile technique when studying educational innovations. Though multilevel modelling is a complex technique (Gorard, 2003), it allows to study of the dependence between individual scores on dependent variables and the nested nature of these scores at a hierarchically higher level. A study of Janssen-Reinen (1996) about the integration of computer use in Dutch primary schools indicates that mainly interaction and communication about technology and computer use exert a direct effect on the intensity of computer use. Riel and Becker also (2001) found a relationship between constructivist orientation and the degree of a teacher's involvement in professional community activities. However, the interplay between variables at school level and teacher level is not that clear. Further research into this point is needed.

The adoption of a multilevel perspective is also in line with the prevalent literature that stresses the need to study ICT use from a socio-cultural perspective. According to Lim (2002), ICT must be studied within a broader context. Next to a statistical analysis of this complex interplay between nested variables, in-depth studies are also needed to identify how teachers respond e.g., to innovative ICT-curricula and give meaning to these new classroom practices. The results of the present study made clear that a clear understanding of educational beliefs is a first step in the development of this deeper understanding of innovations in complex classroom realities.

\section{References}

Albirini, A. (2006). Teachers' attitudes toward information and communication technologies: The case of Syrian EFL teachers. Computers \& Education, 47(4), 373-398.

Becker, H. J. (2001). How are teachers using computers in instruction? Paper presented at the annual meeting of the American Educational Researchers Association, Seattle, April, 2001.

Bellefeuille, G. L. (2006). Rethinking reflective practice education in social work education: A blended constructivist and objectivist instructional design strategy for web-based child welfare practice course. Journal of Social Work Education, 42(1), 85-103.

Beijaard, D. (1998). Persoonlijke onderwijstheorieën van leraren [Personal educational theories of teachers]. In J. Vermunt \& L. Verschaffel (Eds.), Onderwijzen van kennis en vaardigheden [Educating knowledge and skills]. Alphen aan den Rijn. The Netherlands: Samson.

Bradley, G., \& Russell, G. (1997). Computer experience, school support, and computer anxiety. Educational Psychology: An International Journal of Experimental Educational Psychology, 17(3), 267-284.

Bruner, J. S. (1996). The culture of education. Cambridge, Massachusetts: Harvard University Press.

Bryderup, I. M., \& Kowelski, K. (2002). The role of local authorities in the integration of ICT in learning. Journal of Computer Assisted Learning, 18(4), 470-479.

Clark, C. M., \& Peterson, P. L. (1986). Teachers' thought process. In M. C. Wittrock (Ed.), Handbook of research on teaching. New York: Macmillan.

Dede, C. (2000). Emerging influences of information technology on school curriculum. Journal of Curriculum Studies, 32(3), $281-303$.

Demetriadis, S., Barbas, A., Molohides, A., Palaigeorgiou, G., Psillos, D., Vlahavas, I., et al. (2003). "Cultures in negotiation”: Teachers' acceptance/resistance attitudes considering the infusion of technology into schools. Computers \& Education, 41(1), 19-37. 
Duffy, T. M., \& Jonassen, D. H. (1992). Constructivism and the technology of instruction. A conversation. Hillsdale, NJ: Lawrence Erlbaum.

Ertmer, P. (2005). Teacher pedagogical beliefs: The final frontier in our quest for technology integration? Educational Technology Research and Development, 53(4), 25-39.

Fang, Z. H. (1996). A review of research on teacher beliefs and practices. Educational Research, 38(1), 47-65.

Fullan, M. (2001). The new meaning of educational change. London: RoutledgeFalmer.

Ghaith, G., \& Yaghi, H. (1997). Relationships among experience, teacher efficacy, and attitudes toward the implementation of instructional innovation. Teaching and Teacher Education, 13(4), 451-458.

Goodison, T. A. (2002). Learning with ICT at primary level: Pupils' perceptions. Journal of Computer Assisted Learning, 18(3), $282-295$.

Gorard, S. (2003). What is multi-level modelling for? British Journal of Educational Studies, 51(1), 46-63.

Hannafin, M. J., \& Land, S. M. (1997). The foundations and assumptions of technology-enhanced student-centred learning environments. Instructional Science, 25(3), 167-202.

Hawkridge, D. (1990). Who needs computers in school, and why? Computers and Education, 15(1), 1-6.

Hermans, R., van Braak, J., \& Van Keer, H. (2008). Development of the beliefs about primary education scale: Distinguishing a developmental and transmissive dimension. Teaching and Teacher Education, 24(1), 127-139.

Hox, J. J. (1995). Applied multilevel analysis. Amsterdam, The Netherlands: TT-Publikaties.

Hu, P. J.-H., Clark, T. H. K., \& Ma, W. W. (2003). Examining technology acceptance by school teachers: A longitudinal study. Information \& Management, 41, 227-241.

Jackson, P. W. (1986). The practice of teaching. New York: Teachers College Press.

Janssen-Reinen, I. (1996). Teachers and computer use. The process of integrating IT in the curriculum. Enschede, The Netherlands: Reinen.

Kagan, D. M. (1992). Implications of research on teacher belief. Educational Psychologist, 27(1), 65-90.

Kane, R., Sandretto, S., \& Heath, C. (2002). Telling half the story: A critical review of research on the teaching beliefs and practices of university academics. Review of Educational Research, 72(2), 177-228.

Kearns, P., \& Grant, J. (2002). The enabling pillars. Learning, technology, community, partnership. Commonwealth of Australia. Retrieved May 07, 2005, from http://ictpolicy.edna.edu.au.

Keys, P. M. (2007). A knowledge filter model for observing and facilitating change in teachers' beliefs. Journal of Educational Change, 8(1), 41-60.

Kliebard, H. (1989). Problems of definition in curriculum. Journal of Curriculum and Supervision, 5(1), 1-5.

Lim, C. P. (2002). A theoretical framework for the study of ICT in schools: A proposal. British Journal of Educational Technology, 33(4), $411-421$.

Loveless, A., \& Dore, B. (2002). ICT in the primary school. Learning and teaching with ICT. Buckingham: Open University Press.

Lowyck, J. (1994). Teaching effectiveness: An overview of studies. Tijdschrift voor Onderwijsresearch, 19(1), 17-25.

Ministry of the Flemish Community, Department of Education. (2007). Competenties voor de kennismaatschappij. Beleidsplan voor het onderwijs 2007-2009. Retrieved online August, 27, from http://www.ond.vlaanderen.be.

Nezlek, J. B. (2001). Multilevel random coefficient analyses of event- and interval-contingent data in social and personality psychology research. Personality and social psychology bulletin, 27(7), 771-785.

Pajares, M. F. (1992). Teachers beliefs and educational-research. Cleaning up a messy construct.. Review of Educational Research, 62(3), 307-332.

Paris, C., \& Combs, B. (2006). Lived meanings: What teachers mean when they say they are learner-centered. Teachers and Teaching: Theory and Practice, 12(5), 571-592.

Prawat, R. S. (1992). Teachers beliefs about teaching and learning. A constructivist perspective. American Journal of Education, 100(3), $354-395$.

Raths, J. (2001). Teachers' beliefs and teaching beliefs. Early Childhood Research \& Practice, 3(1), 1-10.

Richardson, V. (2003). Preservice teachers' beliefs. In J. Raths \& A. C. McAninch (Eds.), Teacher beliefs and classroom performance: The impact of teacher education. Greenwich, CT: Information Age Publishing.

Riel, M., \& Becker, H. (2000). The beliefs, practices, and computer use of teacher leaders. Paper presented at the American Educational Research Association, New Oreans, April 26, 2000.

Riel, M., \& Becker, H. (2001). Teacher professional engagement and constructivist-compatible computer use. Report no.7, Teaching, learning and computing project. (http://www.crito.uci.edu/tlc/findings/report_7).

Rokeach, M. (1976). Beliefs, attitudes, and values. A theory of organization and change. San Francisco, CA: Jossey-Bass.

Rozell, E. J., \& Gardner, W. L. (1999). Computer-related success and failure: A longitudinal field study of the factors influencing computer-related performance. Computers in Human Behavior, 15(1), 1-10.

Schuh, K. L. (2004). Learner-centered principles in teacher-centered practices? Teaching and Teacher Education, $20(8), 833-846$.

Scrimshaw, P. (2004). Enabeling teachers to make successful use of ICT. Retrieved from http://becta.org.uk.

Shapka, J. D., \& Ferrari, M. (2003). Computer-related attitudes and actions of teacher candidates. Computers in Human Behavior, 19(3), 319-334.

Shulman, L. S. (1987). Knowledge and teaching - Foundations of the new reform. Harvard Educational Review, 57(1), 1-22.

Smeets, E. (2005). Does ICT contribute to powerful learning environments in primary education? Computers \& Education, 44(3), 343-355.

Snijders \& Bosker (1999). Multilevel analysis. An introduction to basic and advanced multilevel modeling. London: Sage Publication.

Tearle, P. (2003). ICT-implementation: What makes the difference? British Journal of Educational Technology, 34(5), 567-583.

Tondeur, J., van Braak, J., \& Valcke, M. (2006). Curricula and the use of ICT in education: Two worlds apart? British Journal of Educational Technology, 1-15. 
Uhlenbeck, A. M., Verloop, N., \& Beijaard, D. (2002). Requirements for an assessment procedure for beginning teachers: Implications from recent theories on teaching and assessment. Teachers College Record, 104(2), 242-272.

van Braak, J. (2001). Factors influencing the use of computer mediated communication by teachers in secondary schools. Computers \& Education, 36(1), 41-57.

van Braak, J., \& Goeman, K. (2003). Differences between general computer attitudes and perceived computer attributes: Development and validation of a scale. Psychological Reports, 92(2), 655-660.

van Braak, J., Tondeur, J., \& Valcke, M. (2004). Explaining different types of computer use among primary school teachers. European Journal of Psychology of Education, 19(4), 407-422.

Van den Berg, R., Vandenberghe, R., \& Sleegers, P. (1999). Management of innovations from a cultural-individual perspective. School Effectiveness and School Improvement, 10(3), 321-351.

Van Driel, J. H., Verloop, N., Van Werven, I., \& Dekkers, H. (1997). Teachers' craft knowledge and curriculum innovation in higher engineering education. Higher Education, 34(1), 105-122.

Watson, D. (2006). Understanding the relationship between ICT and education means exploring innovation and change. Education and Information Technologies, 11(3-4), 199-216.

Williams, D., Coles, L., Wilson, K., Richardson, A., \& Tuson, J. (2000). Teachers and ICT: Current use and future needs. British Journal of Educational Technology, 31(4), 307-320.

Woolley, S. L., Benjamin, W. J. J., \& Woolley, A. W. (2004). Construct validity of a self-report measure of teacher beliefs related to constructivist and traditional approaches to teaching and learning. Educational and Psychological Measurement, 64(2), 319-331.

Zeichner, K. M., \& Tabachnick, B. R. (1985). The development of teacher perspectives: Social strategies and institutional control in the socialization of beginning teachers. Journal of Education for Teaching, 11(1), 1-25. 